\title{
-
}

. 


\section{"Sonderjydske Aarboger"}

udgivne af

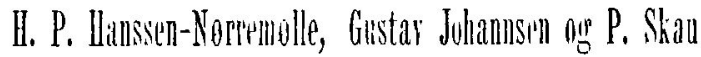
ulkommer fire Gantre aarlior i Hafter paa 5 Ark.

„Nonderjydsk e A arhoger" vil hringe Lidnag til Somderjyllands Historic og Toporgraphi, Skildringer af Folkelivet i Sonderjylland, politiske Afhandlinger on Nutidsforhold i Ssnderiglland $\mathrm{m}$. $\mathrm{m}$.

Subskription paa "Sunderjyd-ke Aarboger" modtages i alle Boglater i sonderjylland, Dammark, Norge og Srerrig. I'riven er 4 Kroner Largangen; for Medlemmer af dinske Foreninger i Nordslesvig 3 Mark.

Nye tiltradende Holdere vil indtil videre kumne faa Ailgangene 1889, 1890 og 1891 for hal ['ris.

\section{Indhold:}

H. F. Feillerg: Erindringer fra et dannk I'riesteliv i Mtellemhlevig . . . . . . . . . . . . . . . . Nid" 1 .

A. D. Jungensen: Eristian VIII. on Norislesvir . . . . . 45.

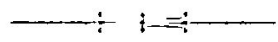

